\title{
The Osteoporotic Effect of Arteriovenous Fistula on the Ipsilateral Upper Extremity in Hemodialysis Patients
}

\section{Hemodiyaliz Hastalarında Arterio-Venöz Fistülün Aynı Taraf Üst Ekstremite Üzerine Osteoporotik Etkisi}

\author{
Betül BAKAN, Ali Murat KALENDER*, Ali ÖZER**, Mustafa Haki SUCAKLI***, Fuat ÖZKAN****, Ekrem DOĞAN***** \\ Sütçü Imam University Faculty of Medicine, Department of Physical Medicine and Rehabilitation, Kahramanmaraş, Turkey \\ * Sütçü Imam University Faculty of Medicine, Department of Orthopedic Surgery and Traumatology, Kahramanmaraş, Turkey \\ **Inönü University Faculty of Medicine, Department of Puplic Health, Malatya, Turkey \\ *** Sütçü Imam University Faculty of Medicine, Department of Family Medicine, Kahramanmaraş, Turkey \\ *** Sütçü Imam University Faculty of Medicine, Department of Radiology, Kahramanmaraş, Turkey \\ ***** Sütçü Imam University Faculty of Medicine, Department of Nephrology, Kahramanmaraş, Turkey
}

\section{Summary}

Objective: Hemodialysis requires an arteriovenous fistula (AVF), the presence of which may influence the structure of nearby bone. This study analyzed the effect of AVF on ipsilateral upper extremity bone mineral density (BMD), as measured by phalangeal radiographic absorptiometry (RA).

Materials and Methods: In this cross-sectional study, phalangeal BMD was measured in both arms by RA in a convenience sample of end-stage renal disease (ESRD) patients with a forearm AVF. Patients were excluded if the patient had pathology which might affect distal arm circulation. BMD values $\left(\mathrm{g} / \mathrm{cm}^{2}\right)$ from forearms with AVF were compared with values from forearms without AVF. Predialysis values of complete blood count, calcium, phosphorus, alkaline phosphatase, parathyroid hormone, urea, creatinine, potassium, albumin, total cholesterol, HDL cholesterol, and LDL cholesterol were determined in all patients; dialysis adequacy values were also calculated. Results: One hundred and sixteen patients agreed to participate in the study. Thirty-three patients were excluded, thus, data were analyzed from 83 patients ( $59 \%$ male, $41 \%$ female, mean hemodialysis time: $156 \pm 6$ months, mean age: $53 \pm 16$ years). AVFs were located in the nondominant hand in all patients. Phalangeal BMD in forearms with AVF $\left(0.28 \pm 0.05 \mathrm{~g} / \mathrm{cm}^{2}\right.$, range: $0.14-0.40$ ) was significantly lower than that in the contralateral forearm $\left(0.30 \pm 0.04 \mathrm{~g} / \mathrm{cm}^{2}\right.$, range: $\left.0.19-0.40, \mathrm{p}<0.05\right)$

Conclusion: In ESRD patients on hemodialysis, BMD is lower in the ipsilateral-to-AVF hand compared to the contralateral-to-AVF hand. In these patients, further investigations should be made to ascertain the ability of $\mathrm{BMD}$ assessment in determining fracture risk and to prompt physicians to initiate treatments which will preserve BMD and reduce fractures. Turk J Phys Med Rehab 2013;59:236-41.

Key Words: Osteoporosis, bone mineral density, phalangeal radiographic absorptiometry, arteriovenous fistula
Özet

Amaç: Hemodiyaliz hastalarındaki arterio-venöz fistül (AVF), çevresindeki kemik dokunun yapısını etkileyebilir. Bu çalışmada falangial radyografik absorbsiyometri (RA) ölçümü ile AVF'nin ipsilateral üst ekstremite kemik mineral yoğunluğu (KMY) üzerine etkisi araştırılacaktır.

Gereç ve Yöntem: Bu kesitsel çalışmada, ön kollarında AVF olan son dönem böbrek yetmezlikli hastaların (SDBY) falangial KMY değerleri her iki koldan RA ile ölçüldü. Distal kol dolaşımını etkileyebilecek herhangi bir patolojisi olan hastalar çalışma dışı bırakıldı. Fistüllü kol falangial KMY değerleri (g/ $\left.\mathrm{cm}^{2}\right)$ fistülsüz kol falangial KMY değerleri $\left(\mathrm{g} / \mathrm{cm}^{2}\right)$ ile karşılaştırıldı. Tüm hastalara diyaliz öncesi tam kan sayımı yapıldı, kalsiyum, fosfor, alkalen fosfataz, paratiroid hormon, üre, kreatinin, potasyum, albümin, total kolesterol, HDL kolesterol ve LDL kolesterol değerleri ölçüldü; diyaliz yeterliliği değerleri hesaplandı.

Bulgular: Çalışmaya 116 hasta katıldı. Otuz üç hasta çalışma dışı bırakıldı 83 hastanın sonucları değerlendirildi. Hastaların \%59'u erkek, \%41'i kadın olup, hemodiyalize girme süreleri $156 \pm 6$ ay ve yaşları $53 \pm 16$ yıldı. AVF tüm hastalarda nondominant koldaydı. Fistüllü kolun falangial KMY değerleri $\left(0,28 \pm 0,05 \mathrm{gr} / \mathrm{cm}^{2}\right.$, aralık $\left.0,14-0,40\right)$, kontralateral kola oranla anlamlı derecede düşǚktü $\left(0,30 \pm 0,04 \mathrm{gr} / \mathrm{cm}^{2}\right.$, aralık $\left.0,19-0,40, p<0,05\right)$. Sonuç: SDBY'li hemodiyaliz hastalarında fistüllü kol falangial KMY değerleri, fistülsüz kol falangial KMY değerlerine göre daha düşük bulundu. Bu hastalarda, kırık riskinin belirlenmesinde KMY ölçümünün rolünü ve koruyucu tedavinin gerekliliğini tespit etmek için daha ileri çalışmalara intiyaç vardır. Türk Fiz Tıp Rehab Derg 2012;59:236-41.

Anahtar Kelimeler: Osteoporoz, kemik mineral yoğunluğu, falangial radyografik absorbsiyometri, arterio-venöz fistül

Address for Correspondence:/Yazışma Adresi: Betül Bakan MD, Sütçü Imam University Faculty of Medicine, Department of Physical Medicine and Rehabilitation, Kahramanmaraş, Turkey Phone: +90 3442212337 E-mail: berdembakan@gmail.com Received/Geliş Tarihi: February/Şubat 2012 Accepted/Kabul Tarihi: May/Mayıs 2013 


\section{Introduction}

Low bone mass is common in end-stage renal disease (ESRD) patients, especially those undergoing hemodialysis. Low bone mass can lead to serious bone problems such as fragility fractures (1-6). Surgically created arteriovenous fistulas (AVF) are widely used in end-stage renal failure patients to provide vascular access for hemodialysis. The incidence of fractures is greater (relative risk 4.4) in hemodialysis patients than in the general population $(1,6)$. Fractures in this population commonly occur at the AVF forearm (3).

Forearm AVF may result in less than normal blood flow and perfusion pressure in the distal parts of the forearm and hand. Experimental studies on the effects of AVF on bone have found alterations in hand perfusion and change in bone structure, but they provided no data on the effect of these structural changes on bone mass (2). The effects of the AVF on the ipsilateral upper extremity have not been widely studied (7).

The aim of this study was to determine the effect of the forearm AVF on bone mineral density (BMD) in ipsilateral and contralateral upper extremities in hemodialysis patients.

\section{Materials and Methods}

This was a cross-sectional study, approved by our hospital ethics committee, and conducted in subjects undergoing hemodialysis at two separate dialysis centers in our city. The study was done from december 2010 to january 2011. Volunteers were recruited from among ESRD patients over 18 years of age who had been on hemodialysis three times a week for more than six months. Patients were denied participation if they had distal arm circulation disorder, previous AVF in the contralateral forearm or graft, and extremity paresis with a history of cerebrovascular disease which might cause a difference in BMD between the two hands. None of the patients had regular exercise programs or hand-strengthening exercises. After giving informed consent, laboratory tests were performed (see below) and BMD was measured in both hands by radiographic absorptiometry (RA), as detailed below. Phalangeal BMD values of the ipsilateral-to-AVF hand were compared with the phalangeal BMD of the contralateral-to-AVF hand.

The following predialysis serum/blood values were measured in all patients: hemoglobin $(\mathrm{Hb})$, calcium, phosphorus, alkaline phosphatase (ALP), intact serum parathyroid hormone (iPTH), blood urea nitrogen (BUN), creatinine, potassium, albumin (Alb), total cholesterol, HDL cholesterol and LDL cholesterol. Adequacy of dialysis was also calculated by the Kt/ $\mathrm{V}$ formal kinetic urea modeling (8).

\section{BMD Measurements}

BMD was measured from the middle phalanges of the second, third and fourth fingers of each hand, using an Alara MetriScan ${ }^{\circledR}$ phalangeal RA device (Alara Inc. Fremont, USA). The device is small enough to fit on a desktop $(41 \mathrm{~cm}$ wide, $42 \mathrm{~cm}$ high, $45 \mathrm{~cm}$ deep) and is light enough to be transportable $(<19$ $\mathrm{kg}$ ). For an exposure, the patient removes any jewelry (when possible) from the non-dominant hand, and places the hand on the moulded support plate. Hand placement is checked to ensure the fingers are flat but not pressed down hard, and that the second phalanges of the middle three digits are within the region of interest marked on the plate. The operator is able to take the exposure using either a button on the front of the device or a remote button connected by a $2 \mathrm{~m}$ lead (9).To record the image, the system uses a storage phosphor plate, which is scanned to extract the image. The hand radiograph is corrected according to a record reference image startup. An aluminum wedge contained in the image is used as an image positioning reference. After the system analyses the image and has segmented soft tissue and bone into separate components, the regions of interest are automatically identified and outlined (10). BMD is expressed in arbitrary units (mineral mass/area) and in grams per square centimeter $\left(\mathrm{g} / \mathrm{cm}^{2}\right)$. T-scores (compares measured BMD with the average BMD for a young healthy subject of the same gender) was derived from a reference database provided by the manufacturer. The database contains data on 1.500 healthy females aged 20-85 years and T-scores were calculated from the group aged 20-39 years. This peripheral densitometry device has the advantages of low cost, portability and low X-ray dose $(<0.02$ $\mu$ SV per examination) (11).

\section{Statistical Analyses}

All data were analyzed using descriptive technique and independent t-test for continuous variables. The Pearson (product-moment) and Spearman's correlations were used to identify predictors of low bone mass. Linear regression analysis was used to measure variables influencing BMD. Analyses were performed by using SPSS version 15.0 for Windows ${ }^{\circledR}$ (SPSS, Inc., Chicago, USA). All tests were two-sided, and a $p$ value of less than 0.05 was accepted as statistically significant.

\section{Results}

Although totally 152 patients undergone hemodialysis from two separate dialysis centers in our city, 116 ESRD patients volunteered for our study. Thirty-three subjects were excluded from the analysis due to technical errors during data storage $(n=4)$, problems with positioning $(n=7)$, orthopedic disorders $(n=4)$, previous AVF in the contralateral forearm or graft $(n=14)$, and extremity paresis with a history of cerebrovascular disease $(n=4)$. The remaining 83 patients (59\% male) had undergone hemodialysis for a mean $\pm S D$ of $48.5 \pm 36.9$ months (range: 6-156 months). Thirty-two of the 34 women were postmenopausal. None were involved in regular exercise programs or routinely did hand-strengthening exercises. Pre-dialysis laboratory findings and BMD results are shown in Table 1.

The AVFs were located on the non-dominant forearm in all patients. Results from both hands of the 83 patients (166 hands) revealed that the ipsilateral-to-AVF phalangeal BMD $(0.28 \pm 0.05$ $\mathrm{g} / \mathrm{cm}^{2}$; range: $0.14-0.40 \mathrm{~g} / \mathrm{cm}^{2}$ ) was significantly lower than the contralateral-to-AVF phalangeal BMD $\left(0.30 \pm 0.04 \mathrm{~g} / \mathrm{cm}^{2}\right.$; range: $\left.0.19-0.40 \mathrm{~g} / \mathrm{cm}^{2} ; \mathrm{p}<0.05\right)$. One patient had ipsilateralto-AVF digital clubbing, one patient had distal ischemia in the ipsilateral-to-AVF hand (cold hand, trophic changes, and hand pain during dialysis - diagnosis confirmed by arteriography), and two patients had an ipsilateral-to-AVF forearm fracture.

The mean $\mathrm{Hb}$ level was $11.7 \pm 1.6 \mathrm{~g} / \mathrm{dL}$ (range: $8.7-16.2 \mathrm{~g} /$ $\mathrm{dL})$; abnormally low ( $<11 \mathrm{~g} / \mathrm{dL})$ in 23 patients $(27.7 \%)$. The mean serum calcium was $8.4 \pm 0.7 \mathrm{mg} / \mathrm{dL}$ (range: $6.8-9.7 \mathrm{mg} /$ $\mathrm{dL})$; the serum calcium was lower than normal $(<9 \mathrm{mg} / \mathrm{dL})$ in 
Table 1. Pre-dialysis laboratory findings and bone mineral density (BMD) in the hands of 83 end-stage renal disease patients undergoing hemodialysis via forearm arteriovenous fistulas (AVF).

\begin{tabular}{lll} 
Variable (normal range) & Mean \pm SD & Range \\
\hline Kt/V & $1.42 \pm 0.27$ & $0-1.81$ \\
Hemoglobin (11-16.5 g/dL) & $11.7 \pm 1.6$ & $8.7-16.2$ \\
Calcium (9-11 mg/dL) & $8.4 \pm 0.7$ & $6.8-9.7$ \\
Phosphorus (1.5-6.8 mg/dL) & $5.3 \pm 1.5$ & $2.0-9.2$ \\
Alkaline phosphatase (98-279 U/L) & $374 \pm 285$ & $120-1982$ \\
iPTH (15-65 pg/mL) & $352 \pm 296$ & $23-1549$ \\
Urea (8-22 mg/dL) & $66 \pm 18$ & $33-118$ \\
Creatinine (0.7-1.4 mg/dL) & $8.3 \pm 2.6$ & $2.4-15.5$ \\
Potassium (4.5-5.5 mmol/L) & $5.1 \pm 0.5$ & $3.7-6.6$ \\
Albumin (3.5-5.0 g/dL) & $3.8 \pm 0.3$ & $3.0-4.3$ \\
Total cholesterol (110-200 mg/dL ) & $174 \pm 43$ & $98-298$ \\
HDL cholesterol (35-55 mg/dL) & $39 \pm 10$ & $19-70$ \\
LDL cholesterol (<130 mg/dL) & $101 \pm 31$ & $41-201$ \\
Ipsilateral-to-AVF phalangeal BMD & $0.28 \pm 0.05$ & $0.14-0.40$ \\
Contralateral-to-AVF phalangeal BMD & $0.30 \pm 0.04$ & $0.19-0.40$ \\
\hline
\end{tabular}

$\mathrm{Kt} / \mathrm{V}$ : Dialysis adequacy values, iPTH: Intact serum parathyroid hormone

61 subjects (73.5\%). The mean serum phosphorus was $5.3 \pm 1.5$ $\mathrm{mg} / \mathrm{dL}$ (range: $2.0-9.2 \mathrm{mg} / \mathrm{dL}$ ); the serum phosphorus was higher than normal $(>6.8 \mathrm{mg} / \mathrm{dL})$ in 12 subjects $(14.5 \%)$. The mean serum ALP was $374 \pm 285 \mathrm{U} / \mathrm{L}$ (range: 120-1982 U/L). The serum ALP was high (>279 U/L) in 47 subjects $(56.6 \%)$. The mean serum $\mathrm{iPTH}$ was $352 \pm 296 \mathrm{pg} / \mathrm{mL}$ (range: $23-1549$ $\mathrm{pg} / \mathrm{mL}$ ); the serum iPTH was high $(>65 \mathrm{pg} / \mathrm{mL}$ ) in 79 subjects (95.2\%). The mean serum urea was $66 \pm 18 \mathrm{mg} / \mathrm{dL}$ (range: $33-118 \mathrm{mg} / \mathrm{dL}$ ). The mean serum creatinine was $8.3 \pm 2.6 \mathrm{mg} / \mathrm{dL}$ (range: $2.4-15.5 \mathrm{mg} / \mathrm{dL}$ ); serum urea and creatinine levels were higher than normal (>22 mg/dL, $1.4 \mathrm{mg} / \mathrm{dL}$ ) in all subjects. The mean serum potassium level was $5.1 \pm 0.5 \mathrm{mmol} / \mathrm{L}$ (range: 3.7 $6.6 \mathrm{mmol} / \mathrm{L})$; the serum potassium level was less than normal $(<4.5 \mathrm{mmol} / \mathrm{L})$ in five subjects $(6.0 \%)$, normal in 69 subjects $(83.1 \%)$, and higher than normal $(>5.5 \mathrm{mmol} / \mathrm{L})$ in nine subjects (10.8\%). The mean serum albumin level was $3.8 \pm 0.3$ $\mathrm{g} / \mathrm{dL}$ (range: $3.0-4.3 \mathrm{~g} / \mathrm{dL}$ ); the albumin was lower than normal $(<3.5 \mathrm{~g} / \mathrm{dL})$ in nine subjects $(10.9 \%)$. The mean serum total cholesterol level was $174 \pm 43 \mathrm{mg} / \mathrm{dL}$ (range: $98-298 \mathrm{mg} / \mathrm{dL}$ ); the serum total cholesterol was higher than normal $(>200 \mathrm{mg} /$ $\mathrm{dL})$ in 19 subjects (22.9\%). The mean serum HDL cholesterol level was $39-10 \mathrm{mg} / \mathrm{dL}$ (range: $19-70 \mathrm{mg} / \mathrm{dL}$ ); the serum HDL cholesterol was lower than normal $(<35 \mathrm{mg} / \mathrm{dL})$ in 22 subjects (26.5\%).The mean serum LDL cholesterol level was $101 \pm 31 \mathrm{mg} /$ dL (range 41-201 mg/dL); the serum LDL cholesterol was higher than normal $(>130 \mathrm{mg} / \mathrm{dL})$ in 11 subjects $(13.2 \%)$.

Correlation analysis was performed among 15 variables (Table 2): ipsilateral-to-AVF phalangeal BMD, contralateralto-AVF phalangeal $B M D$, age, duration of dialysis, serum $\mathrm{Hb}$, calcium, phosphorus, ALP, iPTH, BUN, creatinine, potassium, albumin, total cholesterol, HDL cholesterol, LDL cholesterol level and $\mathrm{Kt} / \mathrm{V}$. The iPTH was divided into two levels (moderate and high; table 3) There was a significant difference in BMD values

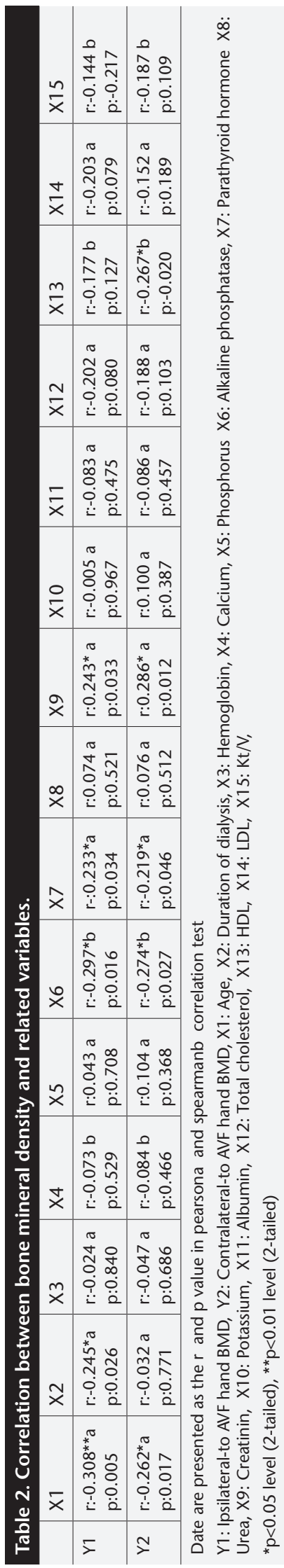




\begin{tabular}{|c|c|c|c|}
\hline Group variable & $\%$ & $\begin{array}{l}\text { AVF Hand } \\
\text { BMD }\end{array}$ & $\begin{array}{l}\text { Contralateral } \\
\text { Hand BMD }\end{array}$ \\
\hline $\begin{array}{l}\text { Age (year) } \\
<50 \\
>50\end{array}$ & $\begin{array}{l}33.73 \\
66.26\end{array}$ & $\begin{array}{l}0.293 \pm 0.034 \\
0.269 \pm 0.055 \\
P=0.043^{*}\end{array}$ & $\begin{array}{l}0.310 \pm 0.028 \\
0.290 \pm 0.046 \\
P=0.049^{*}\end{array}$ \\
\hline $\begin{array}{l}\text { Duration of } \\
\text { dialysis (month) } \\
<24 \\
>24\end{array}$ & $\begin{array}{l}43.58 \\
56.41\end{array}$ & $\begin{array}{l}0.286 \pm 0.044 \\
0.263 \pm 0.050 \\
P=0.034^{*}\end{array}$ & $\begin{array}{l}0.296 \pm 0.043 \\
0.293 \pm 0.040 \\
P=0.727\end{array}$ \\
\hline $\begin{array}{l}\text { iPTH }(\mathrm{pg} / \mathrm{ml}) \\
100-350 \\
>350\end{array}$ & $\begin{array}{l}43.37 \\
48.19\end{array}$ & $\begin{array}{l}0.284 \pm 0.052 \\
0.261 \pm 0.042 \\
P=0.044^{*}\end{array}$ & $\begin{array}{l}0.303 \pm 0.041 \\
0.284 \pm 0.041 \\
P=0.044^{*}\end{array}$ \\
\hline $\begin{array}{l}\operatorname{ALP}(\mathrm{U} / \mathrm{l}) \\
<279 \\
>279\end{array}$ & $\begin{array}{l}41.53 \\
58.46\end{array}$ & $\begin{array}{l}0.300 \pm 0.047 \\
0.264 \pm 0.050 \\
P=0.006^{* *}\end{array}$ & $\begin{array}{l}0.316 \pm 0.041 \\
0.284 \pm 0.081 \\
P=0.002^{\star *}\end{array}$ \\
\hline
\end{tabular}

AVF: Arterio-venöz fistül, BMD: Bone mineral density

of the ipsilateral and contralateral hands between patients with high iPTH level $(>350 \mathrm{pg} / \mathrm{ml})$ and moderate iPTH level (100$350 \mathrm{pg} / \mathrm{ml})(\mathrm{p}=0,044)$. Ipsilateral-to-AVF phalangeal BMD and contralateral-to-AVF phalangeal BMD were highly correlated with age, ALP, iPTH and creatinine. The age, serum ALP, and serum iPTH were negatively correlated with both ipsilateral-toAVF phalangeal BMD and contralateral-to-AVF phalangeal BMD. Duration of dialysis was negatively associated with ipsilateral-toAVF phalangeal BMD $(r=-0.245, p=0.026)$ but contralateralto-AVF phalangeal BMD was not correlated with duration of dialysis $(r=-0.032, p=0.771)$. Other variables were not correlated with ipsilateral-to-AVF phalangeal BMD or contralateral-to-AVF phalangeal BMD (Table 2). The five variables influencing BMD were age, serum ALP, iPTH, creatinine, and duration of dialysis. On linear regression analysis, these variables, age and IPTH were identified as a risk factor for low ipsilateral-to-AVF phalangeal BMD and contralateral-to-AVF phalangeal BMD (age $p=0.003$, iPTH $p=0.003$; age $p=0.017$, iPTH $p=0.004$ ). Duration of dialysis was also identified as a risk factor for low ipsilateral-to-AVF phalangeal BMD, but was not found to be a risk factor for low contralateral-to-AVF phalangeal BMD $(p=0.044 ; p=0.420)$.

\section{Discussion}

Our hemodialysis patients had a lower BMD in their ipsilateral-to-AVF upper extremities than in their contralateralto-AVF upper extremities. Our results were similar to those reported by others who measured BMD from the mid-radius and distal radius in ESRD patients, not from the phalanges as we did $(2,3)$. Muxi et al. (2) reported that forearm AVFs lowered BMD levels in ESRD patients. Fontaine et al. (3) found that hemodialysis patients with fractures had a significantly lower BMD than non-fracture ESRD patients, and a large proportion of the fractures were in the ipsilateral-to-AVF distal forearm.

BMD at lumbar spine, femoral neck and radius sites were measured by dual energy $x$-ray absorptiometry (DXA) in
Muxi (2) and Fontaine study, whereas in our study whole body or lumbar/hip BMD was not measured by DXA which was the limitation of this study.

AVFs affect blood flow in nearby tissues, leading to decreased tissue perfusion and growth $(2,7,12)$. An AVF may lead to alterations in hand perfusion, chronic tissue hypoxia, and distal ischemia (2). All of these effects may result in a decrease in BMD in the ipsilateral-to-AVF hand. A study of 434 accesses in children found hemodialysis access-induced distal ischemia in $9 \%$, but high access flow in only 1\% (9). Frank van Hoek et al. (13) reported a girl with a small ischemic left hand in the ipsilateralto-AVF hand with a patent AVF, whereas the contralateral-toAVF hand was normal. They surmised that the abnormal AVF forearm was due to chronic tissue hypoxia and speculated that the AVF resulted in decreased nutrients being supplied to the distal tissues. Roozbeh et al. (14) reported unilateral digital clubbing in a hemodialysis patient and attributed the findings to chronic tissue hypoxia. In an experimental study on the effect of AVFs on bone healing in dogs, Taşbaş et al. (7) found more dead medullary bone and fewer cartilage cells along the osteotomy line in the ipsilateral-to-AVF tibia. In our study, one patient had unilateral digital clubbing, and another had distal ischemia in the ipsilateral-to-ACF hand with hand pain, cold hand, and trophic changes defined by by clinical examination. Other factors related to AVF, such as immobilization and inactivity of the ipsilateral-to-AVF extremity could have also influenced BMD (15-16).

In patients with chronic kidney disease (CKD), primary muscle, bone, and joint problems are more severe in the extremity with an AVF $(17,18)$. In our study also, patients generally led a sedentary lifestyle and did not use their AVF arms much, even for daily activities. Exercise in these patients is very important; if not done regularly, the patient's quality of life suffers $(17,19)$. Musculoskeletal rehabilitation programs for hemodialysis patients usually include aerobic and strengthening exercises. Regular exercising at home in this population has been found to lower the risk of falls and increase bone density, grip strength, and proximal extremity muscle strength $(17,20)$. Oder et al. (21) observed that ball-squeezing exercises increased the diameter of the AVF immediately afterwards. Leaf et al. (22) reported that hand squeezing exercises with a ball increased blood flow through the AVF and the diameter of the AVF itself. They concluded that these effects might prevent or mitigate vascular problems in these patients. Long-term studies of the effects of upper extremity and general body exercises on AVFs and upper extremity BMD are needed.

ESRD patients usually have accelerated bone loss due to abnormal bone turnover that leads to a high prevalence of osteopenia and osteoporosis $(1,21)$. In the general population, osteoporosis is a main risk factor for fractures, and BMD, routinely measured by DXA, is a quantitative measure of bone mineral deficiency status $(4,6)$. In the absence of axial DXA, current guidelines recommend using peripheral measurements from the hand, forearm or heel to aid in treatment decisions in those with clearly identified clinical risk factors and can be used safely in population screening for osteoporosis $(23,24)$. The UK National Osteoporosis Society suggested that peripheral devices (such as the phalangeal RA device that we used) 
be adopted in a triage role (23-25). A variety of devices are available for assessing sites in the peripheral skeleton, such as the hand, forearm or heel (25). The phalangeal RA device that we used measured phalangeal BMD from the second phalanges of the middle three digits, which made it suitable for use in this study and other studies of screening for osteoporosis $(23,24)$. Blake, et al. (25) recommended the hand as the preferred site for bone densitometry measurements.

Low BMD is associated strongly and consistently with increased risk of fracture in otherwise healthy men and women $(4,26,27)$. ESRD patients with a low bone mass usually have a high incidence of fragility fracture $(8,28,29)$. Decreased bone mass and disruption of microarchitecture occur early in the course of ESRD and worsen with the progressive decline in renal function, so much so that at the time of initiation of dialysis, at least $50 \%$ of patients have had a fracture (30). We found our ESRD patients' phalangeal BMD RA T- score to be lower than -2.5 in 40 patients (48.2\%) with ipsilateral-to-AVF hand and 21 patients $(25.3 \%)$ with contralateral-to-AVF hand. As in our study though, BMD values in the ipsilateral-to-AVF hand were significantly lower than those in the contralateral-to-AVF hand.

We found that age, duration of hemodialysis, iPTH, and ALP levels were negatively correlated with BMD measurements. Other studies have found, like we did, a negative relationship between age and BMD in hemodialysis patients $(1,3)$ whereas others have not found such a relationship (31). Our finding that duration of dialysis was negatively associated with ipsilateral-toAVF phalangeal BMD (but not contralateral-to-AVF phalangeal $B M D$ ) in patients undergoing dialysis for longer periods support our hypothesis that the AVF itself (not hemodialysis per se) is the reason for the lower BMD in the ipsilateral-to-AVF hand. Fountain et al. (3) also reported a negative correlation between duration of dialysis and BMD in hemodialysis patients. They also reported more fractures in the ipsilateral-to-AVF forearm than in the contralateral-to-AVF forearm. Muxi et al. (2) also found the BMD values of the ipsilateral-to-AVF forearm to be lower than those of the contralateral-to-AVF forearm. In their study, however, no significant correlation was found between the BMD of the forearm and duration of dialysis.

Hyperparathyroidism increases cortical porosity, thus, serum PTH level is an important indicator of BMD in patients. However, when hemodialysis is started, the relationship between iPTH and low bone mass becomes complex $(1,31,32)$. For this reason, study results are conflicting regarding the relationship between bone cycle determinators (alkaline phosphatase, calcium, phosphorous, iPTH) and BMD in hemodialysis patients. As we found, Taal et al. (33) and Huang et al. (1), in their study of 151 hemodialysis patients, found a negative correlation between alkaline phosphatase and BMD, and between iPTH and BMD. In other studies, no significant relationship was found between iPTH and BMD $(31,34)$. As did Sit et al. (35) in their study of 70 hemodialysis patients, and Huang GS al.(1) in their study of 63 patients who had been on hemodialysis for at least 6 months (1), we also found no relationship of BMD with calcium and phosphorous.

As a result, BMD is lower in the ipsilateral-to-AVF hand compared to the contralateral-to-AVF hand in hemodialysis patients. Future studies are needed to determine the utility of
BMD values in determining fracture risk, starting treatments which preserve BMD, and guiding long-term management of hemodialysis patients, with the goal of preventing fractures and their associated complications.

\section{Conflict of Interest}

Authors reported no conflicts of interest.

\section{References}

1. Huang GS, Chu TS, Lou MF, Hwang SL, Yang RS. Factors associated with low bone mass in the hemodialysis patients--a cross-sectional correlation study. BMC Musculoskelet Disord 2009;10:60.

2. Muxí A, Torregrosa JV, Fuster D, Peris P, Vidal-Sicart S, Solá O, et al. Arteriovenous fistula affects bone mineral density measurements in end-stage renal failure patients. Clin I Am Soc Nephrol 2009;4:1494-9.

3. Fontaine MA, Albert A, Dubois B, Saint-Remy A, Rorive G. Fracture and bone mineral density in hemodialysis patients. Clin Nephrol 2000;54:218-26.

4. Kanis JA. New osteoporosis guidelines for Canada. CMA 2010;182:1829-30.

5. Shepstone L, Fordham R, Lenaghan E, Harvey I, Cooper C, Gittoes $\mathrm{N}$, et al. A pragmatic randomised controlled trial of the effectiveness and cost-effectiveness of screening older women for the prevention of fractures: rationale, design and methods for the SCOOP study. Osteoporos Int 2012;23:2507-15.

6. Alem AM, Sherrard DJ, Gillen DL, Weiss NS, Beresford SA, Heckbert $S R$, et al. Increased risk of hip fracture among patients with endstage renal disease. Kidney Int 2000;58:396-9.

7. Tasbas BA, Yenidunya S, Hosaka Y, Morohoshi T. Arteriovenous fistula and bone healing: experimental study in the rat. J Reconstr Microsurg 2003;19:395-400.

8. KDOQI, Clinical practice guidelines and clinical practice recommendations for 2006 Updates: Hemodialysis adequacy, peritoneal dialysis adequacy and vascular access. Am J Kidney Dis 2006;48:1-322.

9. Jamal SA, Gilbert J, Gordon C, Bauer DC. Cortical pQCT measures are associated with fractures in dialysis patients. J Bone Miner Res 2006;21:543-8.

10. Boonen S, Nijs J, Borghs H, Peeters H, Vanderschueren D, Luyten FP. Identifying postmenopausal women with osteoporosis by calcaneal ultrasound, metacarpal digital X-ray radiogrammetry and phalangeal radiographic absorptiometry: a comparative study. Osteoporos Int 2005; 16:93-100.

11. Holmberg T, Bech M, Curtis T, Juel K, Gronbaek M, Brixen K. Association between passive smoking in adulthood and phalangeal bone mineral density: results from the KRAM study--the Danish Health Examination Survey 2007-2008. Osteoporos Int 2011;22:2989-99.

12. Bourquelot $P$, Cussenot $O$, Corbi P, Pillion G, Gagnadoux MF, Bensman $A$, et al. Microsurgical creation and follow-up of arteriovenous fistulae for chronic haemodialysis in children. Pediatr Nephrol 1990;4:156-9.

13. Van Hoek F, Scheltinga MR, Krasznai AG, Cornelissen EA. Retarded hand growth due to a hemodialysis fistula in a young girl. Pediatr Nephrol 2009;24:2055-8.

14. Roozbeh J, Sagheb MM, Yavari V, Bastani B, Raeesjalali GA. Unilateral digital clubbing in a hemodialysis patient. Hemodial Int 2010;14:84-6.

15. Demirbag D, Ozdemir F, Kokino S, Berkarda S. The relationship between bone mineral density and immobilization duration in hemiplegic limbs. Ann Nucl Med 2005;19:695-700.

16. Hackelford LC, Le Blanc AD, Driscoll TB, Evans HJ, Rianon NJ, Smith SM, et al. Resistance exercise as a countermeasure to disuse-induced bone loss. J Appl Physiol 2004;97:119-29. 
17. Soyupek F, Aşkın A. Diyaliz hastalarında egzersizin önemi. SDÜ Tıp Fak Derg 2010;17:33-7.

18. Knap B, Buturoviæ-Ponikvar J, Ponikvar R, Bren AF. Regular exercise as a part of treatment for patients with end-stage renal disease. Ther Apher Dial 2005;9:211-3.

19. Storer TW, Casaburi R, Sawelson S, Kopple JD. Endurance exercise training during haemodialysis improves strength, power, fatigability and physical performance in maintenance haemodialysis patients. Nephrol Dial Transplant 2005;20:1429-37.

20. Headley S, Germain M, Mailloux P, Mulhern J, Ashworth B, Burris J, et al. Resistance training improves strength and functional measures in patients with end-stage renal disease. Am J Kidney Dis 2002;40:355-64.

21. Oder TF, Teodorescu V, Uribarri J. Effect of exercise on the diameter of arteriovenous fistulae in hemodialysis patients. ASAIO J 2003;49:554-5.

22. Leaf DA, MacRae HS, Grant E, Kraut J. Isometric exercise increases the size of forearm veins in patients with chronic renal failure. Am J Med Sci 2003;325:115-9.

23. Thorpe JA, Steel SA. The Alara Metriscan phalangeal densitometer: evaluation and triage thresholds. Br J Radiol 2008;81:778-83.

24. Hüner B, Özgüzel MH, Atar S. Osteoporoz tanısında falangeal absorpsiyometri tekniğinin dual enerji X-ışını absorpsiyometri tekniği ile karşılaştııılması. Türk Fiz Tıp Rehab Derg 2009;55:68-72.

25. Blake GM, Chinn DJ, Steel SA, Patel R, Panayiotou E, Thorpe J, et al. A list of device-specific thresholds for the clinical interpretation of peripheral X-ray absorptiometry examinations. Osteoporos Int 2005; 16:2149-56.

26. Jamal SA, Hayden JA, Beyene J. Low bone mineral density and fractures in long-term hemodialysis patients: a meta-analysis. Am J Kidney Dis 2007;49:674-81.
27. Cummings SR, Black D. Bone mass measurements and risk of fracture in Caucasian women: a review of findings from prospective studies. Am J Med 1995;98:24-8.

28. Jamal SA, Leiter RE, Jassal V, Hamilton C J, Bauer DC. Impaired muscle strength is associated with fractures in hemodialysis patients. Osteoporos Int 2006;17:1390-7.

29. Lindberg JS, Moe SM. Osteoporosis in end-state renal disease. Semin Nephrol 1999;19:115-22.

30. West SL, Lok CE, Jamal SA. Fracture Risk Assessment in Chronic Kidney Disease, Prospective Testing Under Real World Environments (FRACTURE): a prospective study. BMC Nephrol 2010;11:17.

31. Özdemir O, Bilgiç MA. Hemodiyaliz hastalarında kemik mineral yoğunluğunun değerlendirilmesi. Türk Fiz Tıp Rehab Derg 2010;56:62-6.

32. Spindler A, Paz S, Berman A, Lucero E, Contino N, Penalba A, et al. Muscular strength and bone mineral density in haemodialysis patients. Nephrol Dial Transplant 1997;12:128-32.

33. Taal MW, Masud T, Green D, Cassidy MJD. Risk factors for reduced bone density in haemodialysis patients. Nephrol Dial Transplant 1999;14:1922-8.

34. Lindergrad B, Johnell O, Nilsson BE, Winklund PE. Studies of bone morphology, bone densitometry and laboratory data in patients on maintenance hemodialysis treatment. Nephron 1985;39:122-9.

35. Sit D, Kadiroglu AK, Kayabasi H, Atay AE, Yilmaz Z, Yilmaz ME. Relationship between bone mineral density and biochemical markers of bone turnover in hemodialysis patients. Adv Ther 2007;24:987-95. 